\title{
THE POSSIBILITY OF THE RIGHT TO RELIGION EMERGING AS A JUS COGENS NORM (PART 1)
}

David Abrahams

BJuris LLB LLM LLM

Lecturer, Faculty of Law

Nelson Mandela University, Port Elizabeth

Tayla Dye

$L L B$

\section{SUMMARY}

This article has been divided into two parts, owing to its nature and scope. The aim of the work is to explore the possibility of the right to religion emerging as a jus cogens norm. In Part One, the concept of jus cogens and its role in the international community, together with the nature of the right to religion, will be discussed. It is on this foundation that the reader will be able to understand why enforcement is such an issue when considering countries such as the Democratic People's Republic of Korea, which serves as a case study and is discussed in detail in Part Two. Gross violations against the right to freedom of religion still exist despite the prevalence of international instruments protecting such rights. Something more needs to be done to hold human rights transgressors to account.

\section{INTRODUCTION}

The right to freedom of religion, thought, conscience and belief is a broad right which is worded in such a way that it allows for any form of belief, or lack thereof, to be recognised and afforded protection. The words "religion, thought, conscious and belief" are often used interchangeably and shall be for the purpose of this discussion. Having the freedom to manifest such a directive of conscience is fundamental to a person's humanity. ${ }^{1}$ Since it is such a crucial part of a person's identity, societal well-being takes strain where this right goes unprotected. The United States Commission on International Religious Freedom has completed studies where the results contained therein reflect this. ${ }^{2}$

\footnotetext{
1 United States of America Department of State Office on International Religious Freedom United States Commission on International Religious Freedom Annual Report 2014 Washington 20142 (hereinafter "USCIRF 2014 Report").

2 USCIRF 2014 Report 3.
} 
These rights are all-encompassing and are inextricably linked to all facets of a person's life. Choosing to believe in something, or choosing not to, underlies many of the choices one makes in one's life. To illustrate this point, it impacts on one's right to freedom of association - to associate oneself with others of like-mindedness; freedom of movement - to be able to move freely to wherever one feels one's mandate takes them; and the right not to be discriminated against on the basis of religion - being able to eat the food one is required to eat in terms of one's faith, or being able to work in the career of their choice without being shunned because of belief or lack thereof.

It is evident that gross violations of the right to freedom of religion take place worldwide, and yet many countries are state parties to international instruments which prohibit such violations. ${ }^{3}$ The International Covenant on Civil and Political Rights, ${ }^{4}$ which broadly encapsulates the right to freedom of religion, belief and conscience, has been ratified by 168 countries. ${ }^{5}$ However, it is well observed that ratification of an international instrument does not necessarily translate into compliance therewith. Enforcement issues plague international law. The question then to be considered is to what extent do countries abide by their treaty obligations and what are the consequences of non-compliance?

Open Doors is a non-profit organisation focused on Christians who are persecuted for their beliefs. Although this organisation focuses on Christians particularly, any country where a particular religion is persecuted, or a particular belief is enforced is problematic. It is through this organisation that major human rights defector, the Democratic People's Republic of Korea, ${ }^{6}$ was identified. ${ }^{7}$

Some of the policies of this country were investigated. It became evident that something more needs to be done to ensure compliance with the right to freedom of religion, belief or conscience. It was through this thought process that the following idea emerged: Would there be any change in the treatment of the right to religion if it were to emerge as a jus cogens? Furthermore, is this emergence possible?

This article firstly seeks to investigate the answers to these questions. It will ultimately be shown, in Part Two of this work, that it is improbable that the right to religion will emerge as a jus cogens, and even if it should, it is proposed that this will make little difference to the enforcement issues which plague the international community. This opinion will be furthered by a detailed discussion of jus cogens, and an analysis of the right to religion in the international community.

\footnotetext{
USCIRF 2014 Report 5.

UN General Assembly International Covenant on Civil and Political Rights 16 December 1966 United Nations Treaty Series Vol 999171 http://www.refworld.org/docid/ 3ae6b3aa0.html (accessed 2015-11-15) (hereinafter "ICCPR").

5 United Nations Human Rights Office of the High Commissioner for Human Rights "Status of Ratification Interactive Dashboard" 25 November 2015 http://indicators.ohchr.org/ (accessed 2015-25-11).

6 Hereinafter "DPRK".

7 Open Doors http://www.opendoorsusa.org/christian-persecution/world-watch-list/ (accessed 2015-11-13).
} 
Secondly, the article considers jus cogens in the international community by way of discussion of the theory of jus cogens, the development of jus cogens, the substantive content of jus cogens, and the legal consequences of jus cogens. Thirdly, the relevant international instruments giving content to the right to religion and the jurisprudence of regional courts in Europe, Africa and the Americas, are explored. A discourse on jus cogens will now follow.

\section{JUS COGENS}

This part considers the controversial topic of jus cogens ${ }^{8}$ in the international community. It seeks to consolidate a multitude of differing views and piece together one comprehensive exposition on the topic.

Firstly, the theory of jus cogens will be considered. A preliminary description will be provided in order to grant a basic understanding of the concept of jus cogens. The fundamental debate between positivists and naturalists will be alluded to as a basis for the controversy surrounding jus cogens. Secondly, the development of jus cogens will be contemplated. Brief reference will be made to the earlier authors on the topic, whose writings predate codification in the $1969^{9}$ and $1986^{10}$ Vienna Convention on the Law of Treaties. The content of these treaties will also be investigated. Four requirements for the formation of jus cogens will be proposed and explained, and the notion of how jus cogens attain its status will be weighed.

Thirdly, the substantive content of jus cogens will be studied. Preliminary points explored will reveal the lack of judicial decisions on the matter. Recourse will therefore be made to Cassese's propositions on generally accepted jus cogens. Since the content of such norms is not firmly settled, it is only the general international law understanding of each norm that can be explored, rather than an accurate reflection of the content of the peremptory aspect of each norm. The following norms will be discussed: the prohibition on the use and threat of force together with the right to self-defence; the principle of self-determination; the prohibition of slavery, genocide, and torture; and fundamental human rights.

Lastly, the legal consequences of jus cogens will be investigated. Not only the straightforward, but so too the lateral consequences proposed by academics, will be elaborated. Considerations of sceptics to the notion of jus cogens will be alluded to in that they feel that jus cogens has no use since there is no definitive outcome. The theory of jus cogens will now be considered.

\footnotetext{
To be used synonymously with the term "peremptory norm".

United Nations Vienna Convention on the Law of Treaties 23 May 1969 United Nations Treaty Series Vol 1155331 http://www.refworld.org/docid/3ae6b3a10.html (accessed 201511-15) (hereinafter "VCLT").

10 United Nations Vienna Convention on the Law of Treaties between States and International Organizations or between International Organizations 12 March 1986 http://www.refworld. org/docid/3ae6b3924.html (accessed 2015-11-15) (hereinafter "1986 VCLT Convention").
} 


\section{Theory of jus cogens}

In a national system of law there is a hierarchical order of sources and of rules of law. For example, a state may have a supreme constitution against which all other values are weighed. No other law or rule may diverge from the values enshrined in such a constitution. However, in an international system of law the same hierarchy was not recognised. Treaty and custom as primary sources of law were of equal status. ${ }^{11}$ These sources are still equal to each other, however, norms that are peremptory in nature have emerged. These norms are known as jus cogens and cannot be derogated from, neither by treaty nor by custom. They therefore acquire superior status to the other sources of international law. ${ }^{12}$ Peremptory norms possess absolute validity, and have emerged to protect the values to which the international community assign the greatest importance. ${ }^{13}$ Theoretically, jus cogens should provide stability in the world order through the superior norms being able to nullify norms in conflict with them. ${ }^{14}$ In this way they solve conflicts between other international law rules. ${ }^{15}$

However, the acceptance of such norms has not been as straightforward as it would appear. The controversy surrounding the existence of such norms is deeply rooted in the age-old debate between naturalists and positivists. While positivists may entirely deny the existence of jus cogens norms, since there is no evidence in positive international law of such a concept, they would be loath to admit that, should two states enter into a treaty agreeing to use force against a third state, such a treaty would be invalid. The very admission of this indicates that, despite the lack of positive proof, there are guiding principles in the international order that are nonderogable. ${ }^{16}$ However, there is not actually a definition that is generally accepted for jus cogens. ${ }^{17}$ It is in this light that the development of jus cogens must be contemplated.

\section{Development of jus cogens}

\section{Historical development}

Even before the definition of peremptory norms appeared in the VCLT, authors had intimated to the existence of jus cogens norms. However, the codification in the VCLT progressively developed the international law of the

\footnotetext{
Cassese International Law 2ed (2005) 198.

Cassese International Law 199.

Orakhelashvili "The Impact of Peremptory Norms on the Interpretation and Application of United Nations Security Council Resolutions" 2005161 The European Journal of International Law 5962.

14 Christenson "Appraisals of the ICJ's Decision: Nicaragua v United States (Merits)" 198781 American Journal of International Law 9395.

15 Linderfalk "The Effect of Jus Cogens Norms: Whoever Opened Pandora's Box, Did You Ever Think about the Consequences?" 2008185 The European Journal of International Law 853854

16 Dixon, McCorquodale and Williams Cases \& Materials on International Law 5ed (2011) 92.

17 Linderfalk 2008 The European Journal of International Law 854.
} 
time. ${ }^{18}$ Quincy Wright first referred to the concept of "illegal treaties" in Costa Rica v Nicaragua ${ }^{19}$ in 1916. ${ }^{20}$ Furthermore, Alfred Verdross wrote about the concept of jus cogens as early as $1937 .{ }^{21}$ Accordingly, at a similar time to the emergence of the concept of obligations erga omnes, ${ }^{22}$ the development of jus cogens seems to have crystallised. ${ }^{23}$ It has later been noted that all jus cogens apply erga omnes, but not all norms that apply erga omnes are jus cogens in character. ${ }^{24}$ In May 1969 the VCLT was concluded. Article 53 states:

"A treaty is void if, at the time of its conclusion, it conflicts with a peremptory norm of general international law. For the purposes of the present Convention, a peremptory norm of general international law is a norm accepted and recognised by the international community of [s]tates as a whole as a norm from which no derogation is permitted and which can be modified only by a subsequent norm of general international law having the same character."

Article 64 declares, "If a new peremptory norm of general international law emerges, any existing treaty which is in conflict with that norm becomes void and terminates." ${ }^{26}$ Article 66(a) expounds that, should there be a dispute regarding how Article 53 or 64 be applied, such a dispute may be submitted to the International Court of Justice for a decision, unless there is agreement on submission to arbitration. ${ }^{27}$ It must be noted that the 1986 VCLT mirrors the abovementioned provisions.

\section{Requirements for formation}

Based on the abovementioned provisions, it can be said that there are four requirements for the formation of a jus cogens norm. Firstly, the norm needs to be general in character in that it is binding on the greater majority of states. Secondly, the international community as a whole needs to recognise the norm as one that is peremptory. ${ }^{28}$ Accordingly, it is not a requirement that all states accept a particular norm as one that is jus cogens. The way in which Article 53 is worded simply suggests that it is sufficient for most of the states to accept the norm in question. ${ }^{29}$ This means that a non-consenting state would be bound by the consent of other states - a divergence from the traditional system to which states had become accustomed. Because jus cogens are universally binding, they are the epitome of "state voluntarism".

18 Wouters and Verhoeven "The Prohibition of Genocide as a Norm of Jus Cogens and its Implications for the Enforcement of the Law of Genocide" 20055 International Criminal LR 401402.

19 Central American Court of Justice (CACJ) Costa Rica v Nicaragua Judgment 30 September 1916 American Journal of International Law 1917111 par 181.

20 Shelton "Normative Hierarchy in International Law" 20061002 American Journal of International Law 291298.

21 Shelton 2006 American Journal of International Law 291.

22 Obligations owed towards the international community as a whole.

23 Bianchi "Human Rights and the Magic of Jus Cogens" 2008193 The European Journal of International Law 491494.

24 Wouters and Verhoeven 2005 International Criminal LR 408

25 Article 53 of the VCLT.

Article 64 of the VCLT.

Article 66(a) of VCLT.

Wouters and Verhoeven 2005 International Criminal LR 402.

29 Cassese International Law 201. 
Even a state that is a persistent objector is bound. Jus cogens is not something that a state can refuse to ratify, or contract with another outside of. ${ }^{30}$ Thirdly, no deflection therefrom is permitted. ${ }^{31}$ Lastly, such norms can only be changed by way of another norm of equal importance. ${ }^{32}$

Be that as it may, there is no straightforward criterion by which one can decide how to identify which general rules of international law constitute jus cogens norms. ${ }^{33}$ The International Law Commission to the General Assembly felt it fitting to leave the content of the rules provided for in Article 53 to state practice and to determinations made by international tribunals. ${ }^{34}$

\section{How jus cogens attain its status}

Likewise, scholars disagree about how peremptory norms attain their status. ${ }^{35}$ Some argue that they are created by treaty, while others contest that such norms can only arise out of customary law. ${ }^{36}$ Hannikainen and Browlie are in support of jus cogens deriving from customary law, while Weil argues that, because jus cogens can be affirmed without state practice or agreement by all states, such norms cannot derive from custom. ${ }^{37}$ Moreover, jus cogens are less open to change than usual customary international law. $^{38}$

In light thereof, Article 53 of the VCLT uses the terminology "peremptory norm of general international law". ${ }^{39}$ This could suggest derivation from custom, yes, but general international law need not be state practice per se. $^{40}$ It is therefore understandable why there is major criticism over the failure of jus cogens to comply with a necessary aspect of law - certainty. ${ }^{41}$

In furtherance of the debate, Askari proposes various ways in which jus cogens norms can form from other sources of international law. Firstly, treaty law is a way of explaining the content of a rule, and how no derogation therefrom should be permitted. The alternative source is customary international law. In fact, many authors, such as D'Amato and Brownlie, see jus cogens as a "stronger type of customary international law". Simma and Alston regard general principles as being more informative of jus cogens than customary international law. ${ }^{42}$

30 Neuman "Import, Export, and Regional Consent in the Inter-American Court of Human Rights" 2008191 The European Journal of International Law 101117.

31 Wouters and Verhoeven 2005 International Criminal LR 403.

32 Askari 'Girls' Rights under International Law: An Argument for Establishing Gender Equality as a Jus Cogens" 19988 Review of Law and Women's Studies 35.

Dixon et al Cases on International Law 91.

34 Dixon et al Cases on International Law 92.

35 Bassiouni "A Functional Approach to General Principles of International Law" 199011 Michigan Journal of International Law 768801.

36 Bianchi 2008 The European Journal of International Law 493.

37 Roberts "Traditional and Modern Approaches to Customary International Law: A Reconciliation" 200195 American Journal of International Law 757783.

38 Roberts 2001 American Journal of International Law 784.

39 Article 53 of the VCLT.

40 Bianchi 2008 The European Journal of International Law 493.

41 Bassiouni 1990 Michigan Journal of International Law 803.

42 Askari 1998 Review of Law and Women's Studies 7. 
Despite wide recognition of jus cogens in the academic arena, perhaps ad nauseam, state practice and judicial opinions have not been as hasty to assert such norms. National and international tribunals, however, seem to be closer to recognition of the concept. ${ }^{43}$ Nevertheless, in spite of the surrounding controversy, there has been a developing unanimity in this regard. Unfortunately, it has not reached a point where there is actual, effective enforcement of jus cogens norms. ${ }^{44}$ The following norms are generally accepted as being jus cogens.

\section{Substantive content of jus cogens}

\section{Preliminary points}

To date, there has been no judicial dispute as to the nature of a jus cogens rule. Furthermore, there has been no decision - neither by the International Court of Justice nor any tribunal - directly over whether a particular norm is peremptory or not. ${ }^{45}$ The International Law Commission ${ }^{46}$ initially made a few suggestions as to what would be peremptory in nature, but did not state that such norms were actually peremptory. However, the ILC and different scholars have been citing them as if they have been agreed upon. ${ }^{47}$ It does, however, seem that the world agrees that "the most basic norms protecting fundamental values of the international community are jus cogens". ${ }^{48}$

Cassese proposes that the road to understanding how to identify jus cogens leads through Article 19 of the previous Draft Articles on State Responsibility, ${ }^{49}$ which has subsequently been deleted. Therein mention was made of "norms laying down international obligations 'so essential for the protection of fundamental interests of the international community that [their] breach [was] recognised as a crime by the community as a whole"'. The following norms were referred to - norms prohibiting aggression; promotion of the principle of self-determination; prohibition of slavery; prohibition of genocide; and prohibition of apartheid. Cassese further proposes that the prohibition of the use or threat of force should appear on this list. ${ }^{50}$ Despite this proposition, it is advanced that the prohibition of the use or threat of force falls under the umbrella of "norms prohibiting

43 Shelton 2006 American Journal of International Law 292.

44 De Wet "The Prohibition of Torture as an International Norm of Jus Cogens and its Implications for National and Customary Law" 2004151 The European Journal of International Law 97120.

45 Cassese International Law 202.

46 Hereinafter "ILC".

47 Christenson 1987 American Journal of International Law 98.

48 Uhlmann "State Community Interests, Jus Cogens and the Protection of the Global Environment: Developing Criteria for Peremptory Norms" 199811 Georgetown International Environmental LR 101102.

49 International Law Commission "Draft Articles on State Responsibility with Commentaries thereto adopted by the International Law Commission on First Reading" (January 1997) http://legal.un.org/ilc/texts/instruments/english/commentaries/9_6_1996.pdf (accessed 2015-11-15).

$50 \quad$ Cassese International Law 202. 
aggression". The ban of torture also appears on his list. Further, the fundamental principles of humanitarian law are, too, jus cogens. ${ }^{51}$

It is therefore apparent that there is an innate relationship between human rights and jus cogens norms. ${ }^{52}$ However, Meron warns that prioritising certain human rights as peremptory norms could have the effect of undermining other human rights that are well established in customary international law. ${ }^{53}$ Authors, such as Howse and Mutua, argue that human rights law is jus cogens in nature. ${ }^{54}$ However, Sajo disputes this position by noting that just because such rights are undisputed, it does not automatically follow that they are jus cogens.

It is seemingly uncontested that human rights such as the right to be free from genocide, slavery, torture, inhuman treatment or punishment, have been elevated to the status of jus cogens norms, but what do these words mean? One cannot assign one's own definitions to such words - thus there is a definitional problem. Furthermore, once there is a working definition, where did it come from? Thus there is a source problem. There needs to be an objectively verifiable international law source. ${ }^{55}$ Having said that, the following is an exposition on the various jus cogens and the general understanding that seems to be attached to each norm.

\section{The prohibition on the use and threat of force and the right of self-defence}

The prohibition on the use of force and the right to self-defence is universally applicable, and developed in terms of customary international law. ${ }^{56}$ It is further reiterated in Article 2(4) of the Charter of the United Nations. ${ }^{57}$ It is stated:

"All Members shall refrain in their international relations from the threat or use of force against the territorial integrity or political independence of any state, or in any other manner inconsistent with the Purposes of the United Nations."

The International Court of Justice ${ }^{59}$ stated in Nicaragua $v$ United States of America that this principle, as enunciated in the UN Charter, is an accurate reflection of the customary international law position. ${ }^{60}$ The Court held that

\footnotetext{
Cassese International Law 203.

Bianchi 2008 The European Journal of International Law 491.

Christenson 198781 American Journal of International Law 97.

Sajo "Socioeconomic Rights and the International Economic Order" 200235 New York University Journal of International Law and Politics 221223.

55 D'Amato "Human Rights as Part of Customary International Law: A Plea for Change of Paradigms" 1995/96 25 Georgia Journal of International and Comparative Law 4749.

56 Linderfalk 2008 The European Journal of International Law 860.

57 United Nations Charter of the United Nations 24 October 19451 UNTS XVI, http://www.refworld.org/docid/3ae6b3930.html (accessed 2015-11-15) (hereinafter "UN Charter").

58 Article 2.4 of the UN Charter.

59 Hereinafter "ICJ".

60 ICJ Military and Paramilitary Activities in and against Nicaragua (Nicaragua v United States of America) Judgment 27 June 1986 ICJ Reports 1986 par 188.
} 
the prohibition of the use of force is one of the founding pillars of international law. ${ }^{61}$

Accordingly, after the scare of World War I and World War II, the world community was dedicated to the notion of world peace as a supreme goal. It is in this context that states were willing to place such limitations on their sovereignty as to agree to desist from the threat or use of force. ${ }^{62}$ There are exceptions to the ban. That being self-defence ${ }^{63}$ and enforcement action by regional agencies. ${ }^{64}$ Only military force is prohibited. ${ }^{65}$ Furthermore, it is only the use or threat of force by a state in respect of another. A state is, therefore, not proscribed from using force to quell a rebellion within their state, for example. After 1945, Article 2.4 developed into a jus cogens norm which binds non-member states too. ${ }^{66}$ Linderfalk describes the jus cogens nature of the norm as follows:

"If, in the conduct of its international relations, a state resorts to force directed against the territorial integrity and political independence of another state, or inconsistent with the purposes of the United Nations, then this skill shall be considered a violation of the international jus cogens."

\section{The principle of self-determination}

The principle of self-determination seems to be firmly rooted in international law, particularly in three spheres - an anti-colonialist standard; a ban on foreign military occupation; and in the requirement that all racial groups have extensive access to government. As reflected in the Declaration on Principles of International Law Concerning Friendly Relations and Cooperation among States in Accordance with the Charter of the United Nations, ${ }^{68}$ the anti-colonialist standard is reflected by the rule that peoples under colonial rule have the option of associating with whichever other independent state they so choose, or may choose to establish its own sovereign state. Such choices - external self-determination - are also available to those peoples that have undergone foreign military occupation. Those racial groups who do not have full access to government may choose either external self-determination, or internal self-determination. ${ }^{69}$ The latter refers to "the pursuit of its political, economic, social and cultural development within the framework of an existing state". ${ }^{70}$

61 Glassman "The Evolution of the Prohibition of the Use of Force and its Conflict with Human Rights Protection: Balancing Equally Forceful Jus Cogens Norms." 201116 UCLA Journal of International Law \& Foreign Affairs 345349. Cassese International Law 55.

Article 51 of the UN Charter.

Article 53 of the UN Charter.

Note that this is in spite of Brazil proposing that economic measures be banned too.

Cassese International Law 56.

Linderfalk 2008 The European Journal of International Law 860.

68 UN General Assembly Declaration on Principles of International Law concerning Friendly Relations and Cooperation among States in accordance with the Charter of the United Nations 24 October 1970 A/RES/2625(XXV) http://www.refworld.org/docid/3dda1f104.html (accessed 2015-11-15) - (hereinafter "1970 UN Declaration on Friendly Relations").

Cassese International Law 61.

70 Cassese International Law 62. 
Other general principles in international law have emerged to set the general standard from which customary and treaty law on the subject matter should be interpreted and applied. In Western Sahara the ICJ described this right of self-determination in that it "requires a free and genuine expression of the will of the peoples concerned."

In addition to the custom that exists, Article 1 of the ICCPR and the International Covenant on Economic, Social and Cultural Rights ${ }^{72}$ expresses the right to internal self-determination. ${ }^{73}$ So too does Article 1 and Article 55 of the UN Charter. The right is further affirmed in the Vienna Declaration and Programme of Action, ${ }^{74}$ as well as the 1970 UN Declaration on Friendly Relations. The United National Human Rights Commission reaffirmed this norm as having jus cogens status. ${ }^{75}$

\section{Prohibition against slavery}

Slavery is defined in the League of Nations Convention to Suppress the Slave Trade and Slavery ${ }^{76}$ as "the status or condition of a person over whom any or all of the powers attaching to the right of ownership are exercised". ${ }^{77}$ The Supplementary Convention on the Abolition of Slavery, the Slave Trade and Institutions and Practices Similar to Slavery of $1956^{78}$ further elaborated on the obligations of states in relation to abolition of slavery. ${ }^{79}$ There are alternative definitions provided by the UN and the Rome Statute of the International Criminal Court, ${ }^{80}$ but this has not changed the international legal context in a meaningful way. ${ }^{81}$ Other instruments giving effect to this

71 ICJ Western Sahara Advisory Opinion Judgment 16 October 1975 ICJ Reports 1975 par 55.

72 UN General Assembly International Covenant on Economic, Social and Cultural Rights 16 December 1966 United Nations Treaty Series Vol $9933 \mathrm{http}: / / \mathrm{www}$.refworld. org/docid/3ae6b36c0.html (accessed 2015-11-15) - (hereinafter "ICESCR").

73 Cassese International Law 62.

74 UN General Assembly Vienna Declaration and Programme of Action 12 July 1993 A/CONF.157/23 http://www.refworld.org/docid/3ae6b39ec.html (accessed 2015-11-15) par 2-3.

75 UN Commission on Human Rights, Situation in occupied Palestine 14 April 2003 E/CN.4/RES/2003/3 http://www.un.org/en/terrorism/pdfs/2/G0514744.pdf (accessed 201511-15).

76 League of Nations Convention to Suppress the Slave Trade and Slavery 25 September 192660 LNTS 253 Registered No $1414 \mathrm{http} / / / \mathrm{www}$.refworld.org/docid/3ae6b36fb.html (accessed 2015-11-16) (hereinafter "Slavery Convention").

77 Article 1.1 of the Slavery Convention.

78 UN General Assembly Supplementary Convention on the Abolition of Slavery, the Slave Trade, and Institutions and Practices Similar to Slavery 30 April 1956 Res 608(XXI) www.ohchr.org/EN/ProfessionalInterest/Pages/SupplementaryConventionAbolitionOfSlaver y.aspx (accessed 2015-11-16).

79 UN Commission on Human Rights Abolishing Slavery and its Contemporary Forms 2002 HR/PUB/02/4, http://www.ohchr.org/Documents/Publications/slaveryen.pdf (accessed 201511-16) par 16 (hereinafter "UN Abolishing Slavery publication").

80 UN General Assembly Rome Statute of the International Criminal Court (last amended 2010) 17 July 1998 ISBN 92-9227-227-6 http://www.refworld.org/docid/3ae6b3a84.html (accessed 2015-11-16).

81 UN Abolishing Slavery publication par 18. 
prohibition include The Universal Declaration of Human Rights; ${ }^{82}$ the ICESCR; and the ICCPR. ${ }^{83}$

\section{Prohibition against genocide}

Article II of the Genocide Convention defines "genocide" and describes the requirement of "specific intent to destroy a national, ethnic, racial or religious group". ${ }^{84}$ The 1948 Genocide Convention has been ratified by 134 countries which are obliged to prevent genocide, and who are in agreement that genocide is a crime. No statutory limitations apply to genocide. Wouters and Verhoeven argue that inclusion of the prohibition against genocide in decisions of the International Criminal Tribunal for the Former Yugoslavia, the International Criminal Tribunal for Rwanda and the International Criminal Court indicated the jus cogens nature of this prohibition. ${ }^{85}$ They further held that the status of the prohibition against genocide as a jus cogens norm has been confirmed in a few cases of the ICJ. For example, in the Advisory Opinion concerning Reservations to the Genocide Convention, ${ }^{86}$ the Court reiterated the binding nature of this prohibition on all states - even on such states which are not party to the Convention. ${ }^{87}$

\section{Prohibition against torture}

Article 5 of the Universal Declaration of Human Rights pronounces that "[n]o one shall be subjected to torture or to cruel, inhuman or degrading treatment or punishment". ${ }^{88}$ Furthermore, in the United Nations Convention against Torture, "[e]ach [s]tate [p]arty shall take effective legislative, administrative, judicial and other measures to prevent acts of torture in any territory under its jurisdiction". ${ }^{89}$ It is further required that "[e]ach [s]tate [p]arty shall

82 UN General Assembly Universal Declaration of Human Rights 10 December 1948217 A (III) http://www.refworld.org/docid/3ae6b3712c.html (accessed 2015-11-16) (hereinafter "UDHR").

83 UN Abolishing Slavery publication par 23-24. For reference to the erga omnes applicability of the prohibition see ICJ Case Concerning the Barcelona Traction, Light and Power Company Limited Judgment (Second Phase) 5 February 1970 ICJ Reports 1970 par 33-34.

84 Wouters and Verhoeven 2005 International Criminal LR 405

85 See eg, International Criminal Tribunal for Rwanda (ICTR) The Prosecutor $v$ Jean-Paul Akayesu Case No ICTR-96-4-T Judgment (Trial Chamber) 2 September 1998; ICTR The Prosecutor v Clement Kayishema Case No ICTR-95-1-A Judgment (Appeals Chamber) 1 June 2001; ICTR The Prosecutor v Alfred Musema Case No ICTR-96-13-A Judgment (Trial Chamber) 27 January 2000; ICTR The Prosecutor v Georges Rutaganda Case No ICTR96-3-T Judgment (Trial Chamber) 6 December 1999; International Criminal Tribunal for the former Yugoslavia (ICTY) The Prosecutor v Goran Jelisic Case No IT-95-10-T Judgment (Trial Chamber) 14 December 1999; ICTY Prosecutor v Radislav Krstic Case No IT-98-33-A Judgment (Appeal Chamber) 19 April 2004; and ICTY Prosecutor v Milomir Stakic Case No IT-97-24-T Judgment (Trial Chamber) 13 July 2003.

86 ICJ Reservations to the Convention on the Prevention and Punishment of the Crime of Genocide Advisory Opinion 28 May 1951 ICJ Reports 1951.

87 Wouters and Verhoeven 2005 International Criminal LR 404.

88 Article 5 of the UDHR.

89 Article 2.1 of the UN General Assembly Convention Against Torture and Other Cruel, Inhuman or Degrading Treatment or Punishment 10 December 1984 United Nations, Treaty Series Vol 146585 http://www.refworld.org/docid/3ae6b3a94.html (accessed 2015-11-16) (hereinafter "Convention Against Torture"). 
undertake to prevent ... other acts of cruel, inhuman or degrading treatment or punishment". ${ }^{90}$ Torture is not prohibited only when on a larger scale, but it is also prohibited when it is an isolated act. ${ }^{91}$ Reference has been made to the universal nature of the prohibition against torture in case law. ${ }^{92}$ As stated in Furundzija, "[c]learly, the jus cogens nature of the prohibition against torture articulates the notion that the prohibition has now become one of the most fundamental standards of the international community." ${ }^{33}$

\section{Fundamental human rights}

There is a question as to whether rights embodied in universal human rights instruments are peremptory. Rights outlined in the ICCPR are a good example. ${ }^{94}$ However, just because the instrument is worded in such a way as to state that no derogation therefrom is permitted, this does not automatically imply that such provisions have attained jus cogens status. This is confirmed by the UN Human Rights Committee in General Comment 29 , wherein it states that "the category of peremptory norms extends beyond the list of non-derogable provisions as given in Article 4, paragraph 2 [of the ICCPR]". ${ }^{95}$

Some academics, such as Engle, assert that all first generation rights ${ }^{96}$ are jus cogens, however, such an assertion appears to be unfounded. ${ }^{97}$ Cassese states that the principle of respect for fundamental human rights is a category of jus cogens, but he then lists the specific human rights known to be jus cogens within themselves (those on apartheid, slavery, genocide, self-determination of peoples). ${ }^{98}$ Therefore, only a few human rights attain peremptory status, despite every human right applying erga omnes. ${ }^{99}$

No state challenges the notion that human rights need to be respected. As a result of the adoption of the UN Charter; the Universal Declaration of 1948; and the two human rights covenants of 1966, together with a number of other general texts, specific conventions and international resolutions, a general principle seems to have emerged, whereby gross and large-scale violations of fundamental rights and freedoms are banned. A practice of state responsibility for substantial infringements of human rights has advanced. There is no requirement of compliance with a specific regulation

\footnotetext{
Article 16 of the Convention Against Torture.

Cassese International Law 445.

See eg, ICTY Prosecutor $v$ Dragoljub Kunarac Case No IT-96-23-T Judgment (Trial Chamber) 22 February 2001 par 483; and ICTY Prosecutor v Zejnil Delalic Case No IT-9621-T Judgment (Trial Chamber) 16 November 1998 par 455.

93 ICTY Prosecutor v Anto Furundzija Case No IT-95-17/1-T Judgment (Trial Chamber) 10 December 1998 par 154.

94 Orakhelashvili 2005 The European Journal of International Law 64.

95 Orakhelashvili 2005 The European Journal of International Law 65.

96 Simply put as negative civil and political rights.

97 Engle "Universal Human Rights: A Generational History" 200612 Annual Survey of International \& Comparative Law 219255.

98 Cassese International Law 65.

99 Dinstein "The Erga Omnes Applicability of Human Rights" 199230 Archiv des Volkerrechts Third States and Sanctions in Public International Law 1617.
} 
on human rights; rather there is a prohibition on repeated infringement on basic rights or categories of rights. ${ }^{100}$

\section{Legal consequences of jus cogens}

In addition to grappling with the content of jus cogens, what is equally important to establish, are the consequences of deviation therefrom. All of the possible effects of jus cogens remain to be seen and are still being debated by academics and in practice. ${ }^{101}$ Linderfalk argues that the effect of jus cogens norms is far greater than previously thought. ${ }^{102}$ Such effects were not contemplated when the VCLT was drafted, but its limited scope of application has developed over the years. ${ }^{103}$ Ultimately the effects can be summarised as invalidation of any acts or transactions that are incompatible with them to ensure their superiority. ${ }^{104}$

Previously, only a state having ratified the VCLT and the treaty which they wished to have declared void for derogating from a jus cogens, could have invoked the relevant provisions of the VCLT ${ }^{105}$ However, since the content of the VCLT has evolved as a customary norm, it has emerged that any state that is directly affected by the treaty in question may invoke the invalidity of the treaty, despite not having ratified it. Cassese puts forth that the custom has developed that, not only norms which are invalid for inconsistency with jus cogens, but also normative acts executed by international subjects and other legal standards not incorporated into treaties. $^{106}$

Therefore, the most obvious legal consequence of jus cogens norms is that any treaty or custom contrary to the norm is void ab initio. It can, however, be envisaged that, should there be a single derogating provision, it is unlikely that a court will declare the entire treaty void, but rather the single provision in question. Furthermore, it is likely that, should the provision be capable of an interpretation that would render it consistent with jus cogens rather than inconsistent, then the former interpretation should be preferred. ${ }^{107}$ However, if one considers the practicality of such a consequence one is left with the consideration that it is unlikely for a treaty to provide for a state of affairs that are in violation with peremptory norms. For example, would a state conclude a treaty with another state agreeing to sell slaves in the modern world? This is improbable. ${ }^{108}$

If the treaty itself is not in conflict with the particular norm, but it would produce an effect that is - through the exercise of obligations in terms of such treaty - then a state should not follow through with such an obligation. For example, a state which has an obligation in terms of a treaty to extradite

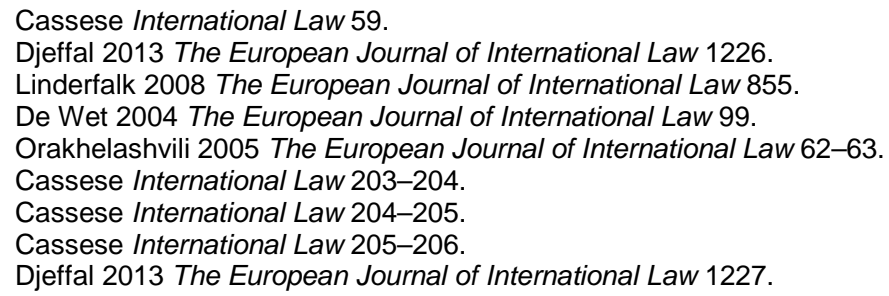


certain persons, but such persons will be subjected to cruel, inhuman and degrading treatment through torture in the other state. The extradition provision is not in itself contrary to the peremptory norm of the prohibition of torture, but, in such circumstances, exercise of the obligation would result in a violation of the norm. Such an obligation should not be complied with. ${ }^{109}$

Jus cogens has other effects too. It could have a possible deterrent effect in that it protects non-derogable values. It could prevent the recognition of a particular state where it has emerged from aggression or denial of human rights to attain the markers of statehood. ${ }^{110}$ Furthermore, it must prevent recognition by states of any situation which came about as the result of a breach of jus cogens norms. ${ }^{111}$ Any reservations to treaties made that are inconsistent with jus cogens would be inadmissible ${ }^{112}$ As already alluded to, the possible violation of jus cogens could give a state grounds not to comply with an extradition treaty that they would ordinarily have to comply with.

In addition, violation of jus cogens could remove state immunity. Certain amnesty laws could be inapplicable where they violate jus cogens. Moreover, where one acts in violation of a jus cogens norm, the state can be granted universal criminal jurisdiction over the perpetrators. ${ }^{113}$ Additionally, where a state could usually breach an international law and justify such a breach with necessity, should the law in question be a jus cogens, such a justification would not be valid. ${ }^{114}$

Furthermore, actions by organisations such as the United Nations Security Council, ${ }^{115}$ are subject to jus cogens. ${ }^{116}$ This would result in a UNSC resolution being void, should it be in contravention with a peremptory norm. ${ }^{117}$ Lastly, jus cogens norms should be considered in judicial processes when judicial officers have to grapple with competing principles and ultimately need to uphold the integrity of international law as a whole. ${ }^{118}$ By illustration, the Inter-American Court of Human Rights have shown that, where a state violates the American Convention of Human Rights and such a violation is also a violation of jus cogens, "a more extensive remedy" is likely to be available. ${ }^{119}$

States that are not directly affected by violations of jus cogens norms may bring the matter of any violation before the ICJ, provided the Court has jurisdiction to hear the matter. ${ }^{120}$ Every state in the international community

109 De Wet 2004 The European Journal of International Law 99.

110 Cassese International Law 207.

11 Shelton 2006 American Journal of International Law 308.

12 Cassese International Law 207.

113 Cassese International Law 208.

114 Linderfalk 2008 The European Journal of International Law 868.

115 Hereinafter "UNSC".

116 Orakhelashvili 2005 The European Journal of International Law 69.

117 Shelton 2006 American Journal of International Law 308.

118 Ibid.

119 Neuman 2008 The European Journal of International Law 117 - In this regard see InterAmerican Court of Human Rights (IACHR) Case of Goiburu v Paraguay Series C No 153 Merits, Reparations and Costs 22 September 2006 par 68; and IACHR Case of the GomezPapuiyauri Brothers v Peru Series C No 110 Merits, Reparations and Costs 8 July 2004 par 37 of separate opinion of Judge AA Cancado Trindade.

120 Wouters and Verhoeven 2005 International Criminal LR 409. 
has an obligation to protect jus cogens norms. ${ }^{121}$ In other words, it is not only the immediately damaged state that is able to institute action against a violator of jus cogens norms. ${ }^{122}$

Notwithstanding the possible legal consequences that could ensue from violation of jus cogens, such outcomes are yet to be seen in the international dispute resolution arena. ${ }^{123}$ However, this does not diminish the fact that the very presence of jus cogens has the potential to guide state conduct. Other sceptics disagree and argue that there is no legal use for jus cogens simply because there cannot be a definitive legal outcome. ${ }^{124}$ Questions remain from the very inception of jus cogens. Who is empowered to determine jus cogens norms? What process do norms undergo that they might ultimately reach jus cogens status? Once such a norm has been determined, how is it enforced? What is the extent of impact on a domestic legal system? What judicial redress is available where there is disagreement of the existence and scope of a jus cogens norm? ${ }^{125}$ Jus cogens norms are criticised for being "empty". Such laws lack effectiveness because states have not internalised them as normative standards against which their actions and laws should be compared. They are seemingly aspirational rather than regulatory. ${ }^{126}$ The following part will consider the content of the right to religion as an international standard.

\section{THE RIGHT TO FREEDOM OF BELIEF, CONSCIENCE AND RELIGION}

This part outlines the content of the right to religion as an international standard by looking at the relevant international instruments as well as regional case law.

The first part of the discussion will consider the relevant international instruments by looking at the contents thereof, as well as possible limitations within the instruments pertaining to the right to freedom of religion. The second part investigates the deeper content of the right by examining the jurisprudence of regional courts in Europe, Africa and the Americas. It is herein that one can understand how the courts have applied the various international instruments, which will now be discussed.

\section{International instruments}

After World War II, the world was determined to prevent such an event from ever occurring again. As such, the UDHR was birthed. Article 18 of the instrument reads, "Everyone has the right to freedom of thought, conscience and religion; this right includes freedom to change his religion or belief, and

\footnotetext{
Wouters and Verhoeven 2005 International Criminal LR 413

Uhlmann 1998 Georgetown International Environmental LR 102.

123 Cassese International Law 209.

124 Fabri "Enhancing the Rhetoric of Jus Cogens" 2012234 The European Journal of International Law 10491052

125 Fabri 2012 The European Journal of International Law 1053

126 Roberts 2001 American Journal of International Law 769.
} 
freedom ... to manifest his religion". ${ }^{127}$ This includes the right to have a religion, or have none at all. ${ }^{128}$ Accordingly, these rights are available to all regardless of "race, colour, sex, language, religion, political or other opinion, national or social origin, property, birth or other status". ${ }^{129}$ Limitations to the right to religion will only be permissible, where they are "determined by law solely for the purpose of securing due recognition and respect for the rights and freedoms of others and of meeting the just requirements or morality, public order and the general welfare in a democratic society". ${ }^{130}$ The UDHR is the cornerstone of international human rights law. It serves to inform states and make recommendations as to the underlying standard. As such it is an ethical and political force rather than being legally binding. ${ }^{131}$

Later, other instruments emerged to give further content to the UDHR ideal. Article 18 of the ICCPR expands on the notion of the right to religion. ${ }^{132}$ It states that freedom to adopt a religion individually or in community with others, and to practice such belief is included in the right to freedom of thought, conscience and belief. ${ }^{133}$ Furthermore, coercion which prevents choice of religion is unacceptable. ${ }^{134}$ In terms of the ICCPR the freedom of thought or conscience is absolute. However, it is the freedom to manifest such beliefs that is subject to certain limitations. The ICCPR expands on the limitations outlined in the UDHR. ${ }^{135}$ One can only limit the freedom of manifestation of belief in such a way determined by law that is necessary for the safety of the public, its order, health, morals or in the protection of fundamental rights and freedom of others.

Additionally, other relevant provisions must be noted. Parents or guardians should be able to inform and educate their children as to their religious or other beliefs in a way they deem to be necessary. ${ }^{137}$ Article 20 of the ICCPR prohibits "advocacy of national, racial or religious hatred that constitutes incitement to discrimination, hostility or violence". ${ }^{138}$

The right to religion bears much weight in the ICCPR. Article 4 pronounces that a state party to the Covenant cannot derogate from Article 18 for any reason - not even in a time of public emergency. ${ }^{139}$ Article 27 pertains to ethnic, religious or linguistic minorities, and states that such groups should not be prevented from practising, or professing their religion, or speaking their language. ${ }^{140}$

127 Article 18 of the UDHR.

128 Davis "The Veil That Covered France's Eye: The Right to Freedom of Religion and Equal Treatment in Immigration and Naturalization Proceedings" 2010103 Nevada LJ 732754.

129 Article 2 of the UDHR.

130 Article 29(2) of the UDHR.

131 Cassese International Law 2ed (2005) 381.

132 Article 18 of the ICCPR.

133 Article 18(1) of the ICCPR.

134 Article 18(2) of the ICCPR.

135 Greenfield "International Law, Religious Limitations and Cultural Sensitivity: The Park 51 Mosque at Ground Zero" 201125 Emory International LR 13171332.

136 Article $18(3)$ of the ICCPR.

137 Article 18(4) of the ICCPR

138 Article 20 of the ICCPR.

139 Article 4 of the ICCPR.

140 Article 27 of the ICCPR. 
The Declaration on the Rights of Persons Belonging to National or Ethnic, Religious and Linguistic Minorities ${ }^{141}$ further elaborates this. Article 14 of the Convention on the Rights of the Child applies the aforementioned rights specifically to children too ${ }^{142}$ It must be noted that further rights linked to the right to religion are also provided for in such instruments. Such rights include the right to life ${ }^{143}$ the right to be free from torture ${ }^{144}$; the right to liberty and security of person; ${ }^{145}$ the right of peaceful assembly; ${ }^{146}$ the right to freedom of association; ${ }^{147}$ and the right to equality. ${ }^{148}$

The United Nations Declaration on the Elimination of All Forms of Intolerance and of Discrimination Based on Religion or Belief ${ }^{149}$ provides insight into how the right to religion should be interpreted, despite the instrument's soft law status. ${ }^{150}$ It illustrates the ICCPR's guarantees. ${ }^{151}$ It describes the right to religion in terms of individual or community practises; in private or in public; and in terms of manifestation of belief by way of "worship, observance, practice and teaching". ${ }^{152}$ A person cannot be coerced into belief or lack thereof. ${ }^{153}$ These rights can only be limited in a way "prescribed by law ... necessary to protect public safety, order, health or morals or the fundamental rights and freedoms of others". ${ }^{154}$

Article 6 of the 1981 Declaration lists a number of freedoms included in the right to freedom of thought, conscience, religion or belief. ${ }^{155}$ In addition thereto, the United Nations Resolution on the Elimination of All Forms of Intolerance and Discrimination Based on Religion or Belief of 14 March 2006 recognises the 1981 Declaration, and further condemns intolerance or

141 UN General Assembly Declaration on the Rights of Persons Belonging to National or Ethnic, Religious and Linguistic Minorities 20 December 1993 A/RES/48/138 http://www.refworld.org/docid/3b00f302c.html (accessed 2015-11-23).

142 Article 14 of UN General Assembly, Convention on the Rights of the Child: Resolution/Adopted by the General Assembly 5 December 1989 A/RES/44/25 http://www. refworld.org/docid/5290a5fc4.html (accessed 2015-11-23).

143 Article 6 of the ICCPR.

144 Article 7 of the ICCPR.

145 Article 9 of the ICCPR.

146 Article 21 of the ICCPR.

147 Article 22 of the ICCPR.

148 Article 26 of the ICCPR.

149 UN General Assembly Declaration on the Elimination of All Forms of Intolerance and of Discrimination Based on Religion or Belief 25 November 1981 A/RES/36/55 http://www.refworld.org/docid/3b00f02e40.html (accessed 2015-11-23) (hereinafter "1981 Declaration").

150 Bennoune "Secularism and Human Rights: A Contextual Analysis of Headscarves, Religious Expression, and Women's Equality Under International Law" 200745 Columbia Journal of Transnational Law 367400.

151 Witte and Green "Religious Freedom, Democracy, and International Human Rights" 2009 23 Emory International LR 583591.

Article 1(1) of the 1981 Declaration.

Article 1(2) of the 1981 Declaration.

154 Article 1(3) of the 1981 Declaration.

155 Article 6 of the 1981 Declaration - Witte and Green 591 propose that such freedoms include the rights to worship and assemble; to maintain charitable and humanitarian institutions; to acquire and use ritual objects and materials; to produce and disseminate publications; to teach religion; to solicit and receive financial and other charitable contributions; to designate religious leaders; to celebrate holy days and days of rest, and to communicate to those within and without the faith both nationally and internationally. 
discrimination on the basis of religion. ${ }^{156}$ It urges states to protect these rights. ${ }^{157}$ It recognises the intolerance and violence aimed at specific religious groups, specifically Islamophobia, anti-Semitism and Christianophobia. ${ }^{158}$ It further details what needs to be done in order to remedy such concerns. Various other international instruments have been adopted and contain the protection of the right to religion. ${ }^{159}$ It is in this context that an analysis of the right to freedom of religion will follow.

\section{Analysis of the right to freedom of religion}

The right to religion cannot simply be a natural law, where there is no binding legal force. Without the right to religion, there cannot be harmony between different groups of people, religious or not.

\section{The basis of the right to freedom of religion}

Arifin proposes that freedom of religion is based on eight norms. The first two norms are internal and external freedom. Internal freedom refers to the fact that each individual has the right to religion and may adopt, defend or even change religion. The external aspect pertains to the freedom to express the religion. In other words, it is the manifestation of such belief. Manifestation can take place privately, publically, individually, or collectively with other believers. ${ }^{161}$

The third norm is non-coercion. This encompasses the fact that no one can be compelled to practise a particular belief. ${ }^{162}$ The fourth norm is nondiscrimination, which places an obligation upon the state to ensure that believers and non-believers have their freedom of religion guaranteed. The

156 Article 1 of UN General Assembly, Elimination of all forms of Intolerance and of Discrimination based on Religion or Belief 14 March 2006 A/RES/60/166 http://www.refworld.org/docid/4459bfadc.html (accessed 2015-11-23) (hereinafter "2006 Resolution").

157 Article 2 of the 2006 Resolution.

158 Article 3 of the 2006 Resolution.

159 These include Article 9 of Council of Europe, European Convention for the Protection of Human Rights and Fundamental Freedoms, as amended by Protocols No 11 and 144 November 1950 ETS 5 http://www.refworld.org/docid/3ae6b3b04.html (accessed 2015-1123) (hereinafter "European Convention"); Article 12 of Organization of American States (OAS) American Convention on Human Rights "Pact of San Jose" Costa Rica 22 November 1969 http://www.refworld.org/docid/3ae6b36510.html (accessed 2015-11-23) (hereinafter "American Convention"); Article 10 of European Union Charter of Fundamental Rights of the European Union 26 October 2012 2012/C 326/02 http://www.refworld.org/docid/3ae6b 3b70.html (accessed 2015-11-23); Article 8 of Organization of African Unity (OAU) African Charter on Human and Peoples' Rights ("Banjul Charter") 27 June 1981 CAB/LEG/67/3 rev 521 I.L.M. 58 (1982) http://www.refworld.org/docid/ 3ae6b3630.html (accessed 2015-11 23) (hereinafter "African Charter"); and UN Human Rights Committee (HRC) CCPR General Comment No 22: Article 18 (Freedom of Thought, Conscience or Religion) 30 July 1993 CCPR/C/21/Rev.1/Add.4 http://www.refworld.org/docid/453883fb22.html (accessed 201511-23).

160 Soriano "Liberal Democracy and the Right to Religious Freedom" 20133 Brigham Young University LR 581583.

161 Arifin "Indonesian Discourse on Human Rights and Freedom of Religion or Belief: Muslim Perspectives" 20123 Brigham Young University LR 775781.

162 Arifin 2012 Brigham Young University LR 781. 
fifth norm is the right of parents and guardians to conduct religious and moral education for their children. It is the obligation of the state to ensure this and to protect the child's right to freedom of religion. ${ }^{163}$

Arifin refers to the sixth norm as "corporate freedom and religious status". What is meant by this is simply that collectively religious groups must have the freedom to form associations. The seventh norm is acceptable limitations to the external right to religion. The right is subject to a law that protects public safety, order, health, morality and other fundamental rights. ${ }^{164}$

Lastly is the norm of non-derogability. The rights to freedom of religion should not be diminished, even where there is a state of emergency. ${ }^{165}$ It must be noted that non-derogability is not synonymous with the term "peremptory" in the technical sense of the word. As has been previously discussed, the fact that the ICCPR states that the rights contained therein are non-derogable does not immediately equate such rights to jus cogens. ${ }^{166}$

\section{Limitations to the right to freedom of religion}

In terms of the ICCPR the freedom of thought or conscience is absolute. ${ }^{167}$ However, it is the freedom to manifest such beliefs that is subject to certain limitations. The ICCPR expands on the limitations outlined in the UDHR. ${ }^{168}$ In the Siracusa Principles on the Limitation and Derogation Provisions in the International Covenant on Civil and Political Rights ${ }^{169}$ the limitations to the freedoms provided for in the ICCPR came under scrutiny and were further clarified. Any limitation needs to be in accordance with the purport of the ICCPR. Limitations "may not be discriminatory against a certain group, must be a necessary response to the public need, and must be proportional". ${ }^{170}$ Each of the international instruments providing for the right to religion have their own wording, albeit similar, for the respective limitations clauses.

Despite the recognition of the right to religion, there still exists gross religious persecution throughout the world. ${ }^{171}$ The defence hereto seems to be the idea of "cultural relativism". ${ }^{172}$ However, cultural relativism can no longer be relevant considering the ratification of the various international human rights instruments already discussed. ${ }^{173} \mathrm{~A}$ discussion on how each regional court has dealt with the interpretation of the respective instruments and enforced them will follow.

163 Arifin 2012 Brigham Young University LR 782.

64 Ibid.

165 Ibid.

166 See earlier discussion on fundamental human rights.

167 See earlier discussion on international instruments.

168 Greenfield 2011 Emory International LR 1332.

169 UN Commission on Human Rights The Siracusa Principles on the Limitation and Derogation Provisions in the International Covenant on Civil and Political Rights 28 September 1984 E/CN.4/1985/4 http://www.refworld.org/docid/4672bc122.html (accessed 2015-11-23).

170 Greenfield 2011 Emory International LR 1333.

171 Soriano provides the following examples - the Baha'i in Iran; the Ahmadis in Pakistan; the Buddhists in China-Tibet; members of the Falun Gong religion in China; Christians in Saudi Arabia; and atheists in Indonesia.

172 Soriano 2013 Brigham Young University LR 585.

173 Arifin 2012 Brigham Young University LR 779. 


\section{Council of Europe}

\section{Criticism of the European Convention}

Within the European context, the right of the individual to freedom of religion has been considered in relation to the right of the particular religious institutions to exist and have autonomy. While the individual right to religion is still protected, the extent of such protection is dependent upon the particular state offering it. Restrictions on the right are therefore permissible, provided they do not culminate in an absolute bar on such freedom. ${ }^{174}$

The European Convention has been criticised for being unsuccessful in the protection of the rights of religious minorities. The Council of Europe stepped in and drafted the Framework Convention for the Protection of National Minorities. ${ }^{175}$ However, this too has been dubbed unsuccessful due to a "weak enforcement mechanism". ${ }^{176}$

\section{European Court of Human Rights}

\section{(i) Formation of the European Court of Human Rights}

The European Convention founded the European Court of Human Rights ${ }^{177}$ to ensure compliance with it. ${ }^{178}$ The Court's jurisprudence has developed over the years, and more and more decisions regarding the right to religious freedom have been handed down. ${ }^{179}$

In determining whether limitation of the rights enshrined in Article 9 of the European Convention are acceptable, the ECHR will consider whether the limitation is linked to a legitimate governmental aim, and whether achievement of such aim is proportional to the limitation. Where there are competing issues to be considered, the ECHR will consider the "margin of appreciation", or leeway, to be given to the states. The purview of such margin is dependent upon the context of each case. Should the issue at hand be one closely linked to personal identity, or where it links with the fundamental concept of democratic values, the margin is restricted. ${ }^{180}$

\section{(ii) Freedom to manifest one's religion or belief}

Freedom of religion by necessary implication includes the freedom to manifest one's belief. Such manifestation may take place in public or in

\footnotetext{
174 Stuart "Freedom of Religion and Gender Equality: Inclusive or Exclusive?" 201010 Human Rights LR 429432.

175 Council of Europe Framework Convention for the Protection of National Minorities 1 February 1995 ETS 157 http://www.refworld.org/docid/3ae6b36210.html (accessed 201511-23).

176 Baillie "Protection of Religious Minorities in Europe: The Council of Europe's Success and Failures" 2007-2008 23 American University International LR 617620

177 Hereinafter "ECHR".

178 Baillie 2007-2008 American University International LR 624.

179 Baillie 2007-2008 American University International LR 626.

180 Stuart 2010 Human Rights LR 434.
} 
private, and "may take the form of worship, teaching, practice and observance." ${ }^{181}$ In order for an action to signify manifestation and fall under the purview of Article 9 of the European Convention, there must be an intimate link between the action and the religious belief. ${ }^{182}$

In the case of S.A.S v France ${ }^{183}$ a Muslim French national complained that her right to freedom of religion had been violated when she was prevented from wearing her full-faced veil in public, that being clothing she is required to wear in terms of her faith. ${ }^{184}$ It was argued that the law enacted to ban this had two legitimate purposes, namely public safety as well as protecting others' rights and freedoms. ${ }^{185}$ Regarding the protection of public safety, the court found that this could be achieved in another way. ${ }^{186}$ Regarding the protection of others' rights, the court rejected the arguments furthered in respect of gender equality and human dignity, ${ }^{187}$ but accepted that seeing a person's face for the purposes of socialisation is a minimum requirement for life in society. ${ }^{188}$

The Court went on to note that the issue was the hiding of one's face and the risk that that posed, rather than prohibition of clothing with a religious connotation. ${ }^{189}$ Furthermore, the fine that was imposed for contravention of the prohibition was a light penalty. ${ }^{190}$ Therefore, such a measure was found to be proportionate, and Article 9 of the European Convention had not been contravened. ${ }^{191}$

In Eweida $v$ The United Kingdom, the applicants complained of not being able to manifest their religion sufficiently. Two of the applicants had issue with being unable to wear a cross around their necks at their workplace. Another two applicants complained of action being taken against them at the workplace because they would not perform activities which they felt condoned homosexuality. ${ }^{192}$ With respect to the first applicant, the Court found that there had been interference with her rights in terms of Article 9 of the European Convention. ${ }^{193}$ She worked for British Airways, who had sent her home when she refused to hide her cross from view. Visibly wearing a cross was in contravention of company uniform codes. ${ }^{194}$ The court had to balance the applicant's desire to communicate her central belief to others with the company's desire to portray a particular corporate image. ${ }^{195}$ The court considered that the subtlety of wearing a cross could not seriously

181 ECHR Eweida $v$ The United Kingdom Case No 48420/10 59842/10 and 36516/10, Judgment (Fourth Section) 15 January 2013 par 80.

182 Eweida $v$ The United Kingdom supra par 82.

183 ECHR S.A.S v France Case No 43835/11 Judgment (Grand Chamber) 1 July 2014.

184 S.A.S v France supra par 3.

185 S.A.S v France supra par 34

186 S.A.S v France supra par 139

187 S.A.S v France supra par 120.

${ }^{188}$ S.A.S v France supra par 141.

S.A.S v France supra par 151.

S.A.S v France supra par 152.

S.A.S v France supra 157.

192 Eweida $v$ United Kingdom supra par 3.

Eweida v United Kingdom supra par 91

194 Eweida $v$ United Kingdom supra par 90.

195 Eweida v United Kingdom, par 94. 
impinge on the interests of others, and in that vein, British Airways had breached Article 9 of the European Convention. ${ }^{196}$

With respect to the second applicant, although the Court also found there to be an infringement of her rights in terms of Article 9, such an infringement was justified for the purposes of health and safety considering her position as a nurse in a geriatric ward. ${ }^{197}$ With respect to the third and fourth applicants, the Court found that there was no violation of Article 9. ${ }^{198}$

The third applicant refused to be a designated registrar of civil marriages, stating that she could not participate in the creation of something which she believed to be contrary to God's will. This resulted in the loss of her job. ${ }^{199}$ The Court had to consider whether the authority's unwillingness to make an exception for her resulted in a contravention of Article 9 of the European Convention. ${ }^{200}$ Bearing in mind that same-sex couples' rights are also protected by the Convention, the Court had to consider that the local authority had the scope to balance these rights. Since the policy adopted by the local authority was in protection of same-sex couples' rights, the Court considered that the authority did not exceed "the margin of appreciation available to them". 201

\section{(iii) Obligation to disclose religious convictions}

Up until 2006, it was a requirement in Turkey that a person's religion be reflected on their identity cards. ${ }^{202}$ After 2006 , it became optional. ${ }^{203}$ In 2010, the Court in Sinan Isik $v$ Turkey held that Article 9 of the European Convention had been violated through any indication of a person's religion on the card, be it optional or not. Not only do people have the right to manifest their religion, but they also have the right not to be compelled to divulge their religion. ${ }^{204}$

Moreover, in light of not being compelled to divulge one's religion, the Court had to consider the taking of an oath in criminal proceedings. When witnesses are about to testify in court, they are asked to place their right hands on the Bible and swear to tell the truth. Such witnesses also have the option of making a declaration instead. In doing so, such witnesses are

196 Eweida $v$ United Kingdom, par 95.

197 Eweida v United Kingdom, par 99

198 Eweida v United Kingdom, par 105 and 110

199 Eweida $v$ United Kingdom, par 102.

Eweida v United Kingdom, par 104.

201 Eweida v United Kingdom, par 106. The fourth applicant refused to administer psychosexual counselling to same-sex couples. Disciplinary proceedings were brought against him (par 107). Considering that the employer's motivation was to provide "a service without discrimination", they had a wide margin of appreciation to balance the rights at play. Yet again, the court did not consider the margin to have been exceeded (par 109). This reveals that the courts consider such questions on a case-by-case basis. There is no set outcome, but rather, a consideration of the circumstances before it.

202 S 43 of the Civil Registration Act (Nufus Kammu) Law No 1587 - see in Sinan Isik v Turkey par 15 - full citation to follow.

203 S 35(2) of the Civil Registry Services Act (Nufus Hizmetleri Kammu) Law No 5490 - see in Sinan Isik v Turkey, par 17.

204 ECHR Sinan Isik v Turkey Case No 21924/05 Judgment (Second Section) 2 February 2010 par 52. 
forced to reveal that they are not Orthodox Christians. In Dimitras $v$ Greece $^{205}$ the Court had to address this complaint. ${ }^{206}$ The Court found that there had been a violation of Article 9 of the European Convention, where such witnesses are forced to reveal their religious inclinations when opting to make a declaration instead of take an oath and that there was no justification or proportionality to the exercise. ${ }^{207} \mathrm{~A}$ similar question was considered in Alexandridis $v$ Greece, ${ }^{208}$ wherein the Court also ruled that there had been a violation of Article 9 of the European Convention. ${ }^{209}$ The same reasoning was applied in Buscarini $v$ San Marino ${ }^{210}$ in the context of those elected to San Marino Parliament being required to take an oath. ${ }^{211}$

\section{(iv) Recognition of religious communities}

In Hasan and Chaush $v$ Bulgaria ${ }^{212}$ the Bulgarian Government assigned someone the post of Chief Mufti of the Bulgarian Muslim community. ${ }^{213}$ The applicants argued that such forced replacement violated their rights under Article 9 of the European Convention. ${ }^{214}$ With respect to the right to manifest one's religion, the applicants contended that "the right to manifest one's religion in community with others meant that the community should be allowed to organise itself according to its own rules ... thus ... the alleged forced removal of the leaders of the community concerned their individual rights". ${ }^{215}$ This constituted an interference with the organisational life of the community. ${ }^{216}$ The Court confirmed that the state had interfered with freedom of religion. Such interference was in fact arbitrary and found to be a violation of Article 9 of the European Convention. ${ }^{217}$

In Jehovah's Witnesses of Moscow $v$ Russia ${ }^{218}$ the issue at hand was the refusal by the Russian authorities to re-register the religious community in question. ${ }^{219}$ The community had been dissolved and banned. ${ }^{220}$ Despite the dissolution and banning being in accordance with legislation and being done with the aim of protecting the health and rights of others, the decision to dissolve the community was based upon inaccurate facts. Accordingly, the

205 ECHR Dimitras v Greece Case No 36836/09 Judgment (First Section) 2 October 2015.

206 European Court of Human Rights Press Unit Factsheet - Freedom of Religion November 20142 - (hereinafter "ECHR 2014 Factsheet").

207 ECHR 2014 Factsheet 3.

208 Registrar of the European Court of Human Rights "Press release issued by the Registrar: Chamber Judgment Alexandridis v Greece" (12 February 2008) http://hudoc.echr.coe. int/eng-press? $\mathrm{i}=003-2274253-2426441$ (accessed 2015-11-23).

209 ECHR 2014 Factsheet 3.

210 ECHR Buscarini v San Marino Case No 24645/94 Judgment 18 February 1999.

211 Buscarini v San Marino par 40-41.

212 ECHR Hasan and Chaush v Bulgaria Case No 30985/96 Judgment 26 October 2000.

213 Hasan and Chaush v Bulgaria par 23.

214 Hasan and Chaush v Bulgaria par 55.

215 Hasan and Chaush v Bulgaria par 56.

216 Hasan and Chaush v Bulgaria par 66.

217 Hasan and Chaush v Bulgaria par 89.

218 ECHR Jehovah's Witnesses of Moscow v Russia Case No 302/02 Judgment (First Section) 10 June 2010.

219 Jehovah's Witnesses of Moscow v Russia par 43.

220 Jehovah's Witnesses of Moscow v Russia par 102. 
Court found such actions to be in violation of Article 9 of the European Convention. 221

\section{African Commission and Court on Human and Peoples' Rights}

\section{Formation of the commission and court}

The African Charter provides for the formation of the African Commission on Human and Peoples' Rights. ${ }^{222}$ It further describes the functions of such Commission. ${ }^{223}$ On 25 January 2004 the Protocol to the African Charter on Human and Peoples' Rights on the Establishment of an African Court on Human and Peoples' Rights ${ }^{224}$ was entered into force. ${ }^{225}$ In recognition of the mandate of the African Commission on Human and Peoples' Rights, ${ }^{226}$ the African Court was established. ${ }^{227}$ The jurisdiction of the Court extends to the interpretation and application of the Charter. ${ }^{228}$

\section{Displacement of communities}

In Endorois Welfare Council $v$ Kenya ${ }^{229}$ the ACHPR considered a complaint filed by the Centre for Minority Rights Development and the Minority Rights Group International on behalf of the Endorois community. The issue involved the displacement of the community from their ancestral lands. Of particular interest is the allegation that such displacement violated the community's right to practise their religion and culture. ${ }^{230}$ It must be noted that the African Court had not yet been created when the ACHPR heard this matter.

The Government of Kenya denied the community access to their land, an integral part of their religion and culture, in order to create the Lake Hannigton Game Reserve. ${ }^{231}$ Since the community was denied access to religious sites to worship, it was alleged that this contravened Article 8 of the

\footnotetext{
Jehovah's Witnesses of Moscow v Russia par 160.

Article 30 of the African Charter

223 Article 45 of the African Charter. Broadly speaking, such functions include the promotion of human and people's rights (Article 45.1); the protection of such rights (Article 45.2); interpretation of the provisions of the African Charter (Article 45.3); and performing other suitable related tasks (Article 45.4).

224 Organization of African Unity (OAU), Protocol to the African Charter on Human and People's Rights on the Establishment of an African Court on Human and People's Rights, 10 June 1998, http://www.refworld.org/docid/3f4b19c14.html (accessed 2015--11-23) (hereinafter "African Court Protocol").

225 International Federation for Human Rights Practical Guide: The African Court on Human and Peoples' Rights towards the African Court of Justice and Human Rights April 20105.

226 Hereinafter "ACHPR".

227 Article 1 of the African Court Protocol.

${ }^{228}$ Article 3 of the African Court Protocol.

229 African Commission on Human and People's Rights (ACHPR) Centre for Minority Rights Development (Kenya) and Minority Rights Group International on behalf of Endorois Welfare Council v Kenya Case No 276/2003 4 February 2010.

230 Endorois Welfare Council v Kenya par 1.

231 Endorois Welfare Council $v$ Kenya par 3.
} 
African Charter. ${ }^{232}$ The Mochongoi Forest and Lake Bogoria, located within the Game Reserve, are locations used by the community for important cultural and religious ceremonies. ${ }^{233}$ The Lake "is considered the spiritual home of all Endorois, living and dead". It was therefore argued that it forms an integral part of all religious practices and beliefs held by the community. 234 The denial of access to the land therefore interferes with the community's right to practise their religion. ${ }^{235}$

The ACHPR confirmed that access to the land is inextricably linked to the community being able to practise cultural and religious ceremonies, and that denial of access isolates them from feeling a connection to their land and ancestors. ${ }^{236}$ However, in considering whether a violation of Article 8 of the African Charter in fact occurred, the ACHPR had to establish that the ceremonies observed by the community constituted a religion. The ACHPR "is of the view that freedom of conscience and religion should, among other things, mean the right to worship, engage in rituals, observe days of rest, and wear religious garb." ${ }^{237}$ The ACHPR stated:

"This Commission is aware that religion is often linked to land, cultural beliefs and practices, and that freedom to worship and engage in such ceremonial acts is at the centre of freedom of religion."

It confirmed that the community's spiritual beliefs and practices constituted a religion in alignment with the African Charter. ${ }^{239}$ What was left for determination was whether this right to religious freedom had been interfered with. ${ }^{240}$ While the ACHPR agreed that limitation of the rights in the African Charter is possible, it cannot be done in a manner that entirely negates the right. Limitations need to be reasonable and proportionate. Restrictions should be "negligible". 241

In this regard the ACHPR found that denial of access to the Lake was indeed a restriction of the community's right to practise their religion, and that there was no justification therefore. It seems that economic development or ecological protection was not reasons enough to deny the community the right to access the Lake entirely. Kenya thus violated Article 8 of the African Charter. ${ }^{242}$

\footnotetext{
Endorois Welfare Council v Kenya par 76.

Endorois Welfare Council v Kenya par 78

Endorois Welfare Council $v$ Kenya par 79.

Endorois Welfare Council v Kenya par 80.

Endorois Welfare Council v Kenya par 156

Endorois Welfare Council v Kenya par 165.

Endorois Welfare Council v Kenya par 166.

Endorois Welfare Council v Kenya par 168.

Endorois Welfare Council v Kenya par 169.

Endorois Welfare Council v Kenya par 172.

Endorois Welfare Council v Kenya supra par 173.
} 


\section{Inter-American Commission and Court of Human Rights}

\section{Functions of the commission and court}

The Inter-American Commission of Human Rights ${ }^{243}$ and the IACHR are charged with enforcing commitments made in accordance with the American Charter. ${ }^{244}$ The American Commission is charged with the development and awareness of human rights; making recommendations to governments of member states; preparing studies or reports; requesting information from states regarding measures adopted in respect of human rights; responding to member states on inquiries made; taking action on petitions; and submitting annual reports to the General Assembly of the Organisation of American States. ${ }^{245}$ State parties and the American Commission then submit cases to the IACHR. ${ }^{246}$ The jurisdiction of the IACHR extends to "all cases concerning the interpretation and application of the provisions of this Convention that are submitted to it". ${ }^{247}$

\section{Censoring of films}

The IACHR heard a matter pertaining to a film entitled, "The Last Temptation of Christ". ${ }^{248}$ Christ is portrayed in a "deformed and diminished" way in the film. ${ }^{249}$ The American Commission brought the matter before the IACHR against Chile in order for the Court to order that film be published and exhibited. ${ }^{250}$ While the Court had to consider freedom of expression, it also had to consider that such expression could "destroy the sincere beliefs of a great many people." ${ }^{251}$ The American Commission argued that proscription of access to the film interfered with the right to freedom of religion in that a state should not interfere in "adoption, maintenance or change in their personal convictions of a religious or other nature." They argued that persons should be able to view the film that they might form their own opinions about its content. ${ }^{252}$

The IACHR considered Article 12 of the American Convention, and noted that the right to religion extends to the maintenance, change, profession and dissemination of beliefs. The protection thereof must be far-reaching, however, the Court could not find that prohibiting the exhibition of the film impaired any one of the religious rights enunciated above. ${ }^{253}$ It must be noted, however, that the Court found that the state violated the right to

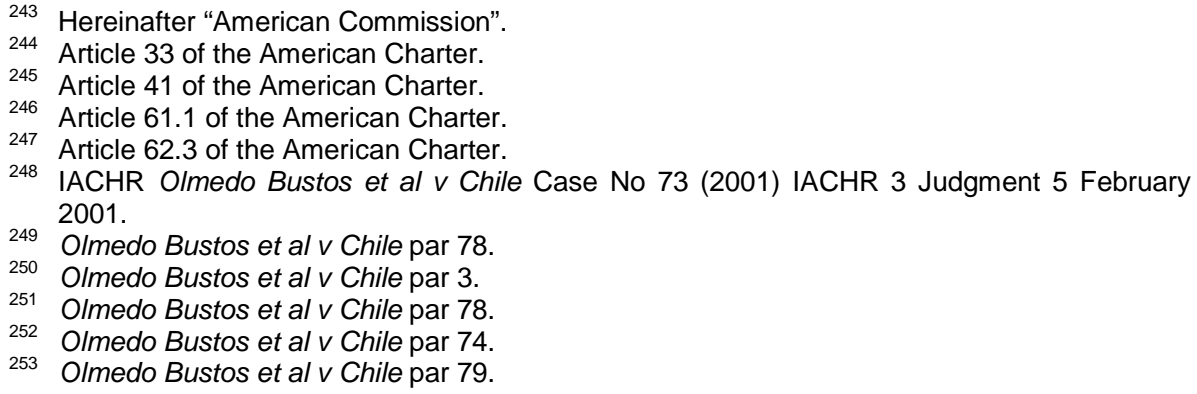


freedom of thought and expression. ${ }^{254}$ What follows is an investigation into the extent to which the DPRK in particular have taken cognisance of the right to religion. The extent of non-compliance will impact upon the question of whether the right to religion should emerge as a jus cogens norm. As stated above, The Democratic People's Republic of Korea serves as a case study, and will address, amongst others, the issue of non-compliance in detail in Part Two.

\section{CONCLUSION}

The question posed in this article is whether it is possible for the right to religion to emerge as a jus cogens. This question has, in part, been considered through a detailed discussion of jus cogens, and an analysis of the right to religion in the international community.

The discussion of jus cogens involved, firstly, a consideration of the theory of jus cogens. A preliminary description was provided for a basic understanding of the topic. The controversy surrounding jus cogens was also alluded to. Secondly, it contemplated the development of jus cogens through brief reference to the authors who wrote on the topic prior to codification of the concept in the VCLT. The content of the VCLT was investigated. Furthermore, the requirements for formation in regard to jus cogens was proposed and explained, and the notion of how jus cogens attained its status was weighed. Thirdly, it studied the substantive content of jus cogens. The following norms were discussed - the prohibition on the use and threat of force together with the right to self-defence; the principle of self-determination; the prohibition of slavery, genocide, and torture, as well as fundamental human rights. Lastly, it involved an investigation into the legal consequences of jus cogens.

The analysis of the right to religion involved a discussion of the content of the right to religion as an international standard by looking at the relevant international instruments, as well as the jurisprudence of regional courts in Europe, Africa and the Americas. This article has therefore sketched the background for a better understanding of the concept of "jus cogens" and its relationship vis-a-vis the right to religion. Part Two will deal with a case study of the Democratic People's Republic of Korea, and it will also provide recommendations in relation to the original question set in this article as to whether there is a possibility of the right to religion emerging as a jus cogens norm.

254 Olmedo Bustos et al v Chile par 103. 